Published in Global Governance: A Review of Multilateralism and International Organizations 2016, issue 22 vol. 3,pp. 331-348.

\title{
What Happened to the Responsibility to Rebuild?
}

\author{
Outi Keranen
}

\begin{abstract}
:
While significant obstacles to the realisation of the responsibility to protect in practice remain, it has nonetheless made considerable progress in transforming from an idea to an emerging norm. At the same time, however, its sister component, the responsibility rebuild has elicited less scholarly and policy attention. The lack of attention to rebuilding responsibilities has been made all the more urgent by the violent aftermath of the first protection intervention in Libya in 2011. Against this backdrop, the article examines the way in which the responsibility to rebuild is understood and operationalized, with reference to Libya and Côte d'Ivoire, theatres of two recent protection interventions. The conceptual evolution of the responsibility to rebuild reveals a distinct shift towards a more statist understanding of the rebuilding phase; what was initially considered a part of the wider international protection responsibility has become to be viewed as a domestic responsibility. This recalibration of the responsibility to rebuild stems from the concept's association with the 'reactive' element of R2P as well as from the changes in the wider normative environment. The more statist understanding of rebuilding responsibilities has manifested itself not only in the emphasis on domestic ownership of the rebuilding process in the wake of protection interventions but also in the reconceptualization of the wider international responsibility to rebuild as a narrower responsibility to assist in building the capacity of the state subjected to protection intervention. This has been problematic in policy terms as the attempt to build capacity through the standard 'statebuilding' measures has resulted at best in negative peace and at worst in armed violence.
\end{abstract}

Keywords: responsibility to rebuild, responsibility to protect, Libya, Côte d'Ivoire

\section{Introduction}

The recent intervention in Libya failed to bring an end to the debates on the salience of the responsibility to protect (R2P) principle. Whilst for some the 2011 intervention signals the emergence of the principle as substantive norm in international politicsi, others point to the exceptional circumstances under which the consensus to intervene 
was achieved and thus remain more cautious about the purported normative shift in the protection responsibilities from the state to the international realm. ii Although significant obstacles to the realisation of the responsibility to protect in practice remain, the principle has nonetheless altered the terms of debate on humanitarian interventions. Not only has it made it harder for states to ride roughshod over their own protection responsibilities outlined in international legal conventions, but perhaps more importantly it has rendered international inaction in the face of mass atrocities more controversial. iii

If the responsibility to react to atrocities in other states has become an influential idea, then what of the associated concept of the responsibility to rebuild? Posing this question is of critical importance if we accept that interventions to halt atrocities alone are insufficient in meeting the protection responsibilities. ${ }^{\text {iv }}$ Yet, the prevention and rebuilding components of the protection principle have attracted less interest, arguably due to the contested nature of the reactive pillar. Although Bellamyv and others have begun to address this lacuna with regard to the prevention responsibilities, relatively little attention has been paid to the notion of the duty to rebuild. The lack of systematic research on the issue has been made all the more urgent by events in Libya where the intervention in the name of the responsibility to protect was undertaken in 2011. Four years into the rebuilding phase marked by international disengagement, Libya has made little headway towards political stability or consolidated sovereignty. Rather than ushering forth a new peaceful Libya, the ousting of Gaddafi has resulted in continuing violence. In Côte d'Ivoire too, another case of where military force was used in the name of protecting populations from mass atrocities, lack of independent judiciary and reconciliation coupled with sporadic violence have threatened to undermine the aim of the R2P intervention to halt armed violence.

In the light of this, the present paper seeks to contribute to our understanding of the less-investigated element of the emerging idea of the responsibility to protect, the obligation to rebuild. The questions that motivate this paper concern the way in which the responsibility to rebuild is understood and operationalised; how the responsibility to rebuild is interpreted and understood by agents undertaking humanitarian interventions, the way in which it has been operationalised and ultimately, what the 
implications are to the responsibility to protect principle at large. The discussion draws on the cases where R2P interventions have so far being undertaken; Libya and Côte d'Ivoire. Although providing a snapshot of the concept's operationalisation rather than body of generalizable evidence, the cases provide an opportune moment to begin examining the aftermaths of protection interventions in two very different contexts.

The findings of the analysis can be summarised as follows. The conceptual evolution of the responsibility to rebuild reveals a distinct shift towards a more statist understanding of the rebuilding phase; what was initially considered a part of the wider international protection responsibility has become to be viewed as a domestic responsibility. The more statist understanding of rebuilding responsibilities has manifested itself not only in emphasis on domestic ownership of the rebuilding process in the wake of protection interventions but also in the reconceptualization of the wider international responsibility to rebuild as a narrower responsibility to assist in building the capacity of the state subjected to protection intervention. The recalibration of the responsibility to rebuild stems from the concept's association with the 'reactive' element of R2P as well as from the changes in the wider normative environment within which rebuilding operations exist. In policy terms the change has been problematic as the attempt to build capacity through the standard 'statebuilding' measures have resulted at best in negative peace (Côte d'Ivoire) and at worst in armed violence (Libya). Whilst the policy implications of the shift have been complex, the move towards emphasising domestic rebuilding responsibilities and espousing vague commitment to capacity-building has enabled the intervening states to maintain policy flexibility with regard to participating in post-intervention rebuilding missions.

As suggested earlier, the line of enquiry developed here speaks to an overlooked dimension of the responsibility to protect. Particularly the early debates on the R2P focused almost exclusively on the responsibility to react. Some work has begun to address this gap in the analysis of R2Pvi. The task of theorising the responsibility to rebuild has, on the other hand, mainly been taken up Just War scholars. Jus post bellum theorists vii, focusing on just ending of wars, have begun to debate whether intervening forces have rebuilding obligations in the context of occupations and regime change operations. Much of the research has been motivated by the commonly, if not 
universally, held view among just war theorists that the aftermath of an intervention is important to the justice of the intervention itself. The question of who ought to bear rebuilding responsibilities following conventional wars, occupations and regime change operations has stimulated lively debate. Elshtain, for one, makes a moral case for the intervener's responsibility to rebuild with reference to the Pottery Barn principle of 'you break it, you own it'viii. From another perspective, Pattison ${ }^{\text {ix }}$ argues that the collective international responsibility to rebuild war-torn or conflict-ridden states ought to be borne by actors most capable of doing so. In most cases the task of rebuilding would fall to the UN and other specialised statebuilding agencies. Others, however, see no logical connection between a just intervention and the rebuilding phase. The argument here is that if an intervention meeting the Just War criteria has been undertaken to protect populations from mass atrocities, those carrying it out owe nothing more to the protected populations ${ }^{\mathrm{x}}$. In asking a set of questions about responsibilities of agents in the aftermath of wars, regime change operations and humanitarian interventions, Just War scholars have contributed to our understanding of the ethics of ending conflicts. Yet, beyond the moral debates of rebuilding responsibilities, a number of questions remain with respect to the understanding and operationalisation of the principle in practice.

In the R2P literature, in turn, rebuilding responsibilities have been largely overlooked. An exception is Schnabel's xi discussion of the concept. He argues that the third element of the R2P had no place in the concept's development as it provided a less vague and flexible set of obligations than prevention and reaction. This was not in the interest of those undertaking interventions. Schnabel also suggests that the lessons of peacebuilding and statebuilding missions in the past decade - half-hearted or short-term engagement is unlikely to result in sustainable peace - have translated into reluctance to emphasise the rebuilding element of R2P. This is clearly an important part of the puzzle of why the responsibility to rebuild has failed to gain traction in policy discussions. Schnabel, however, tells only a part of the story: states operates within normative structures and as a result, are informed by prevalent ideas about appropriate course of action. Understanding why ideas such as the responsibility to rebuild fall out of favour requires not only attentiveness to state interests but also to changing norms on rebuilding missions. This analysis, thus, seeks to add to our existing knowledge on the 
responsibility to rebuild by tracing the evolution of the idea and its operationalization in the context of recent protection interventions. It will begin by tracing the evolution of the concept and then move onto to explaining why the conceptual change has occurred. Finally, the analysis turns to examining the ways in which rebuilding responsibilities are understood and operationalised in practice and what the implications to the R2P as a whole are.

\section{Responsibility to Protect}

The evolution of the responsibility to rebuild is best understood within the wider context the responsibility to protect. The advent of the R2P owes much to the Kosovo intervention in 1999xii. The unauthorised and highly contested intervention in Kosovo raised concerns about the selective use of humanitarian interventions. ${ }^{x i i}$ This led the UN Secretary General Kofi Annan to call for consensus on the new parameters of humanitarian intervention and sovereignty. In response, the Canadian government established the International Commission on Intervention and State Sovereignty (ICISS) which published its report 'the Responsibility to Protect' in 2001. The central contention of the report was that in cases where states failed to protect their citizens from atrocities and crimes against humanity the international community had the ultimate duty to protect and in doing so, use military intervention as a last resort. The ICISS formulated a distinct continuum of responsibilities spanning from prevention to reaction and rebuilding. The preventative phase, according to the report, entailed addressing causes of internal conflict. The 'reactive' pillar, in turn, alluded to the obligation to take action in the face of 'compelling human need'xiv if the state in question was unwilling or unable to do so. This, as the report suggests, could translate into military intervention in extreme circumstances.

The final element of the principle was the responsibility to rebuild, which stipulated post-protection intervention obligation to assist with reconstruction and peacebuilding efforts. The continuum of responsibilities was guided by the rationale that reaction on its own is bound to be ineffective; credible protection of civilians requires prevention and rebuilding. In this sense, then, the three pillars developed in the ICISS report were 
intimately interlinked and seen as a whole that is greater than a sum of its parts. While the vision put forth by the Commission received endorsement from the UN Secretary

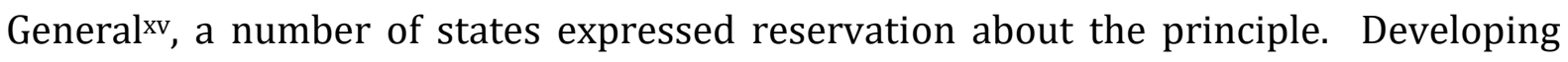
countries in particular saw R2P as a pretext for intervention. These concerns were reflected in the conceptualisation of the R2P in the 2005 UN World Summit Outcome Document; while member states expressed their commitment to the responsibility to protect, the obligations of states were foregrounded at the expense of international protection responsibilities.

\section{Evolution of the Idea}

Concept with much longer pedigree than the R2P is the notion of rebuilding of war-torn states. The Marshall Plan is often mistakenly seen as the predecessor of what is known today as statebuilding. Williams ${ }^{\mathrm{xvi}}$ identifies the Boer War as the first conflict followed by a systematic attempt by an external actor, Great Britain, to reconstruct the war-torn state. The British sought to reform the administrative structures and industry, alongside the policy of promoting English settlement in the Boer republics xvii. The inter-war period, in turn, witnessed a multilateral rebuilding attempt in Austria where the League of Nations initiated an extensive economic rebuilding project. War had destroyed the country's economy and with the view of restoring Austria's position as a financial centre that could stimulate economic growth in Europe, the League developed a plan to reform Austria's economy through turning the country into protectorate xvii. Two decades later, the US-led reconstruction of Germany and Japan entailed similar protectorate-style transfer of authority to the occupying force. The aim of the United States was to ensure rapid economic recovery and democratisation in Europe in order not only to alleviate suffering but also to realise economic and geopolitical policy goals.

During the Cold War years engagement in post-war societies was largely viewed through the prism of superpower competition. The end of the Cold War enabled not only the dispatching UN peacekeepers to conflict zones but also the establishment of what has become known as 'peacebuilding'. Peacebuilding, as defined in the 1992 report 'An Agenda for Peace', refers to the 'identification and support structures which 
will tend to strengthen and solidify peace in order to avoid relapse into conflict'xix Whereas the earlier reconstruction efforts were characterised by attempts to rebuild the status quo ${ }^{\mathrm{xx}}$, the new post-Cold War peacebuilding missions aimed at transforming it. Essential to peacebuilding missions has been the attempt to address the root causes of conflict, whether poverty or structural injustice. The human security-oriented focus underpinning peacebuilding began to be overshadowed by emphasis on strengthening state capacity in the wake of $9 / 11^{x x i}$. Effective state and legitimate institutional structures were seen as the best guarantors of stability. This meant growing emphasis on so-called 'statebuilding' and good governance in post-conflict states. Statebuilding missions became intertwined with counter-terrorism as state failure and weakness were seen as major causes of terrorism.

Although the ICISS was concerned of obligations following protection interventions rather than post-conflict states more generally speaking, it is against this intellectual background that the idea of responsibility to rebuild is best understood. The ICISS sought to represent rebuilding as an obligation rather than a right realised only when states' national interests were at stake. While the obligations of states in situations regarded as occupations are coded in international law, the Commission put forth a set of ideas relating to the responsibilities of the international community following protection interventions. Rebuilding was to be understood as a prescriptive (an obligation) rather than merely a permissive (a right) norm. To this end, the 2001 ICISS report sketched out a set of priorities for the rebuilding phase. Security, the Commission argued, is one of the primary elements of effective rebuilding strategy. It envisaged a role for international actors in realising both immediate concerns, such as ensuring order, and longer-term rebuilding tasks. Justice and reconciliation are highlighted by the Commission as equally important tasks for the rebuilding phase. Judicial reform is considered vital for the realisation of the longer-term ability of the state in question to protect the rights of its citizens. Finally, development is identified as the third priority in the rebuilding phase; economic growth, employment and steady incomes are identified as the key elements disincentivizing return to violence.

The report created a temporal association between intervention and rebuilding: the rebuilding phase is represented as a follow-up for the use of military force for 
protection purposes. This implies that rebuilding is part of the policy toolkit only in extreme cases, where military force is used as a final resortxxii. As to the agents who ought to realise such responsibilities, the Commission identified the UN as the key actor in the rebuilding stage of R2P. Although the report was highly sensitive of the detrimental effects of externally-imposed rebuilding process and emphasised the role of local authorities as partners, it made a case for post-intervention engagement lengthy enough to ensure stabilisation and sustainable peace xxii. Hasty exit or lack of rebuilding strategy, according to the Commission, would be irresponsible and may ultimately undermine the credibility of the responsibility to protect principle. xxiv Following the publication of the Commission's report, the idea of international duty to rebuild was lent credence by the endorsement of the UN Secretary General and the 2004 High Level Panel on Threats, Challenges and Change. The report outlined a vision of states' collective responsibility for each other's security and endorsed the notion of spectrum of protection responsibilities, ranging from prevention and reaction to rebuildingxxv.

At the same time however, states were much more reserved about the international duty to rebuild. This was evident in the omission of the responsibility to rebuild element of R2P in the 2005 UN World Summit Outcome Document. In the negotiations on the content and wording of the R2P paragraphs the notion of continuum of international responsibilities before, during and after humanitarian crises outlined by the ICISS made way for the emphasis on preventative action as the main international responsibility. Although handful of governments, such as those of Mexico, Chile and New Zealand, made references to the sequential nature of international responsibilities as suggested in the ICISS report, the positions of many governments had shifted towards emphasising prevention as the main international obligation ${ }^{\mathrm{xxvi}}$. The shift away from rebuilding responsibilities and towards prevention was particularly evident in the positions of China, Russia and the non-aligned movement (Egypt, Cuba, Iran, India, among others). R2P sceptics, such as Pakistan, argued that 'much greater emphasis in required to prevent outbreak of conflicts...the UN SG and this Council have a clear right to insist a mediatory role in inter-state conflicts. But even in internal situations, an early and active role could be pursued with discretions'xxvii. In another statement, Pakistan made a case for development assistance, fairer terms of international trade and debt relief as a way for developed countries to realise their protection responsibilities ${ }^{\mathrm{xx} v i i i}$. 
Even proponents of the R2P, such as Canada and Sweden, referred to the need to emphasise prevention while remaining silent on rebuilding responsibilities ${ }^{\mathrm{xxix}}$. Similarly, the United States, expressing indirect support for R2P without directly referring to international responsibilities, advocated a focus on preventative measures ${ }^{\mathrm{xxx}}$.

The focus on preventative obligations was reflected in the UN Secretary General's 2009 report 'Implementing the Responsibility to Protect'. The sequential stages of R2P were substituted by three pillars consisting of the protection responsibilities of the state (pillar I), international assistance and capacity-building (pillar II) and timely and decisive response (pillar III). It is Pillar II that is most relevant for the purpose of understanding the evolution of the responsibility to rebuild idea; it sought to coalesce both preventative and rebuilding tasks under the rubric of international assistance and capacity-building. Operational activities such as military assistance to states' unable to deal with armed rebellion and structural measures support for governance reforms were identified as pillar two commitments of international actors. These responsibilities were dispersed among a myriad of international development and human rights actors, including the international financial institutions, UN High Commissioner for Refugees and UNICEFxxi, regional organisations such as the OSCE xxxii and finally, donor governmentsxxxiii. This reorganisation of R2P enabled the divorcing of rebuilding from the 'reactive' element of the principle and conflating it with preventative tasks.

Whereas the pillar II commitments outlined in the 2009 report were both broad and vague and focused primarily on preventative measures, more detailed explanation of pillar II tasks can be found in the subsequent reports by the UN Secretary General. In making a case for R2P as a process of building responsible sovereigns, the Secretary General argued in his 2012 report that pillar II activities should ensure that states have the capacity to meet their pillar I responsibilities and reduce the future need for pillar III action xxxiv. More recently, the 2014 report elaborates on the Pillar II commitments $^{\mathrm{xxxv}}$. The leitmotif of the report is the reinforcement of the capacity of states to meet their protection responsibilities. The Pillar II, according to the report, is premised upon set of five principles; national ownership, mutual commitment to build 
resilience by both domestic and external actors, 'do no harm' by ensuring that international assistance does not contribute to the development of circumstances leading to atrocity crimes, prioritisation of prevention and finally, flexibility in terms of addressing root causes of conflict which vary from society to society.

What is notable in these follow-up reports is the gradual de-emphasis on international responsibilities under Pillar II in favour of more statist understanding of Pillar II commitments. Alongside the above mentioned 2014 report, the most direct articulation of this can be found in the 2011 report on the role of regional organisations in implementing R2P which regards rebuilding responsibilities to lie squarely with the domestic authorities. This indicates that with the reorganisation of the R2P into three

pillars in the 2009 report more than terminology on rebuilding responsibilities has changed; not only are post-intervention rebuilding tasks conflated with preventative, capacity-building measures but the locale of responsibilities has shifted from the international to domestic. The outcome, in the aftermaths of the two Pillar III interventions so far, has been the policy of domestically-led statebuilding. This, as will be argued in the latter part of the paper, has not been conducive to the overall aim of the R2P to prevent conflict.

\section{Explaining and Interpreting the Conceptual Shift}

What accounts for these changes? To provide an answer to this question, it is necessary to turn to the normative environment within which rebuilding operations exist. Research on norms and ideas has shown that 'fit' with existing normative structures is critical factor when it comes to the translation of an idea into a norm ${ }^{\mathrm{xxxvi}}$. While occasionally major turning points such as conflicts or conscience-shocking events prompt the emergence of a norm that challenges the existing normative framework in a given issue area, generally ideas tend to be more acceptable if they fit with the existing set of norms xxxvii. In similar vein, Florinixxxviii argues that the success or failure of new ideas is determined in part by how well they interact the dominant norms in the issue 
area. These insights are important to an understanding of the recalibration of the rebuilding responsibilities that goes beyond narrow focus on material interests.

In terms of thinking about the set of the existing norms on humanitarian interventions, the tension between sovereignty and such interventions is well-established. Solving this tension was, indeed, the rationale behind R2P. Yet, the notion of shared protection responsibilities proposed by the ICISS was unsuccessful in gaining traction with many developing countries. They opposed the initial conceptualisation of R2P as it was regarded as a permit for Western interventionism. It was in fact these concerns that also rendered the rebuilding element unacceptable; as the international responsibilities were seen as a continuum, rebuilding phase would be preceded by international protection interventions on which no consensus existed ${ }^{x x x i x}$. As the former UN Special Adviser on the Prevention of Genocide, Edward Luck, has pointed out, this sequential element, combined with the ICISS report's extensive focus on the use of military force in the implementation of the $\mathrm{R} 2 \mathrm{P}$ rendered the notion of responsibility to rebuild unacceptable to a number of states ${ }^{\mathrm{xl}}$. This was evident in the fact that no reference was made to the responsibility to rebuild in the decision to establish Peacebuilding Commission (PBC) in the World Summit where the R2P in its initial form was discussed. While the Commission would have been the logical institutional home of the responsibility to rebuild, developing countries demanded the divorcing of the PBC from R2P principles xli. As a result, the PBC has played no role in rebuilding operations in post-R2P environments.

If the prevalence of sovereignty rendered the idea of international rebuilding responsibilities short-lived, it is also necessary to understand the ideational changes that were taking place in the wider normative environment on peacebuilding, statebuilding and donor-relations. The argument here is that the idea of responsibility to rebuild emerged into unfavourable normative environment: whist the ICISS proposed international rebuilding obligations, the wider ideas underpinning post-conflict operations and donor-relations reflected the opposite trend. The donor conditionalitydriven development and post-conflict rebuilding strategies began to be replaced by an approach emphasising national ownership in the late 1990s, formalised in the 2005

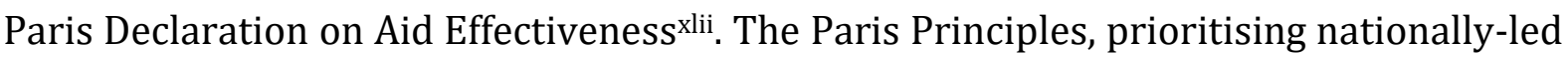


development strategies, have since become influential in the context of post-conflict peacebuilding and statebuilding. This is evident, for instance, in the UN Peacebuilding Commission's policies; its Integrated Peacebuilding Strategies are premised on 'homegrown' rebuilding policies ${ }^{x l i i i}$. Moreover, the presence of developing country representatives in the Commission has ensured that the Paris Principles are incorporated into the UN peacebuilding missions. ${ }^{\text {xliv }}$ More recently, the New Deal on Peacebuilding developed by the G7 countries together with conflict-affected states and aid agencies under the rubric of International Dialogue on Peacebuilding and Statebuilding, is premised on an emphasis on local ownership of capacity-building. Its founding document states that ' transitioning out of fragility is long, political work that requires country leadership and ownership...international partners can often bypass national interests and actors, providing aid in overly technocratic ways that underestimate the importance of harmonising with the national and local context..'xlv

This shift away from top-down, externally-imposed peacebuilding and statebuilding strategies reflect the process of policy learning; heavy-handed rebuilding interventions in the 1990s in Bosnia, Kosovo and East Timor produced dependency and undermined domestic capacity-building and conflict resolution. The Council of Europe, for instance, noted in its 2005 assessment of the post-conflict rebuilding process in Bosnia and Herzegovina that the quasi-protectorate-model of statebuilding deployed in the country was deeply problematic from the point of view of democratisation and, ultimately, Bosnian sovereignty. ${ }^{\mathrm{xlvi}}$ Perhaps more critical part of the policy learning process has been realisation that imposition of statebuilding reforms is unlikely to result in legitimate and sustainable peace, as evidenced by the long-drawn out and expensive rebuilding processes in the Western Balkans, Africa, Afghanistan and Iraq. Particularly the latter two have rendered so-called 'nationbuilding' missions unpopular in Western states. These policy lessons are particularly evident in the Secretary General's 2014 report on Pillar II where the potential of external assistance in capacity-building do more harm than good is a reoccurring theme. 


\section{Operationalisation of Pillar II Commitments}

In what way, then, are Pillar II commitments realised in practice following protection interventions? The aftermaths of protection interventions in 2011 in Libya and Cŏte d'Ivoire provide an opportunity to develop some initial answers in the context of two very different cases. To begin with the Libyan case, the international policy after the 2011 intervention has been one of disengagementxlvii. Four years into the rebuilding phase, Libya has made little headway towards political stability or consolidated sovereignty. Conflict in the new Libyan state has been fueled by a vicious cycle whereby the numerous armed groups that formed during the anti-Gaddafi rebellion have little faith in institutions of the state and those occupying it, while those holding positions in the new governing bodies advocate the incorporation of the armed factions to the official security apparatus of the state. The armed groups, refusing to disarm as former Gaddafi supporters are part of the new governance structures, fill the security and judicial vacuum by running prisons and conducting (often arbitrary) arrests ${ }^{x l v i i i}$. The post-intervention governments have had little success in asserting their authority over myriad of armed brigades who fear the infiltration of the new governance arrangements by figures active the former Gaddafi regime. No substantive disarmament, demobilization and rehabilitation process has taken place due the inability of the Libyan authorities to credibly enforce the process xlix. In the past year the political tensions have boiled over into armed violence and the formation of two rival governments, the internationally-recognized administration in the eastern city of Tobruk and the Tripolibased General National Congress (GNC).

Despite the deep divisions within the country that transpired soon after the fall of the Gaddafi regime, rebuilding measures such as reconciliation and transitional justice highlighted by the ICISS took a back seat in donor governments' funding priorities. The overall locus of international assistance in the immediate aftermath of the intervention was on security, particularly on the country's porous borders. While being supportive of the attempt by the Libyan authorities to stabilise the country, the focus on border security arguably reflected the prioritisation of aspects of security pertinent to intervening countries' national interests. In other words, much emphasis was placed on creating the security apparatus of the Libyan state that could effectively deal with 
transnational problems such as terrorism, weapons smuggling and migration. Little evidence can be found in the immediate aftermath of the intervention of engagement in comprehensive or coherent capacity-building assistance by donor governments as outlined in the Secretary General's reports on R2P and capacity-building under Pillar II. Although the establishment of more extensive peace mission in post-intervention Libya was out of question due to domestic concern that presence of foreign peacekeepers would undermine the legitimacy of the new government, Libyan authorities requested technical advice and assistancel. Some aid initiatives were planned - such as the training of the Libyan army by the US military - and others executed - namely, the Security, Justice and Defense Programme launched by the UK in 2013 to facilitate security sector reform - but ultimately the Libyan authorities were left alone in addressing the post-Gaddafi security vacuum.

The only major international rebuilding body in Libya has been the UN Support Mission in Libya (UNSMIL). The cornerstone of the UN involvement in the post-intervention phase has been the emphasis on the principle of national ownership; this has meant domestic responsibility for building sustainable peace and establishing the strategy for

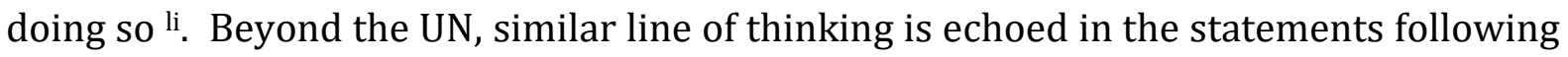
high level international conferences on Libya, namely those held in London (2011) and Paris (2013). Registering concern with the deteriorating security situation in the country, the 2013 Paris Communiquelii for instance noted that 'much now rests on Libya's leadership to carry the political process forward...'. The only domain where international actors were seen as having distinct protection responsibilities was securityliii. In acknowledging the Security Council's protection mandate, the document pointed out the continued duty of NATO to protect following the end of the Gaddafi regimeliv. As suggested above, such responsibility has so far not being met. It is only recently that the approach of the major powers to Libya has begun to change; the rise of the Islamic State in Libya and the growing migration crisis in the Mediterranean have pushed Libya back into the western states' foreign policy agendas. After failed attempts to broker peace between the warring factions in 2014, UN-led peace talks in 2015 led to signing of an agreement that may lead to the establishment of unity government. Yet, at the time of writing, the GNC alongside key militias have refused to sign the agreement which has added weight to the calls for external military intervention in the country. 
The aftermath of the protection intervention in Cŏte d'Ivoire differs in many ways from that of Libya. Whereas the international commitment on the post-intervention rebuilding process in the Libyan case has been weak at best, a more comprehensive UNled peacebuilding operation has taken place in Cŏte d'Ivoire. The operation is a continuation of the decade long UN presence in the country and as such, builds upon existing peacebuilding mission. Following the 2011 intervention the newly established government of Alassane Outtara received extensive foreign aid from France and the EU. The combined donations of France and the EU amounted to over $\$ 700$ million, the bulk of which was directed towards social spendinglv. It is notable that much of the international rebuilding presence in the country rests on the former colonial power

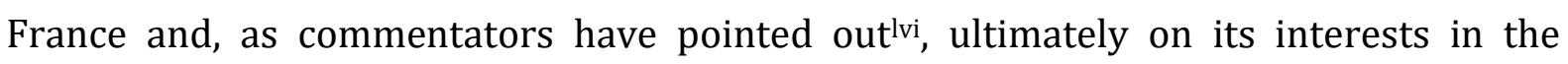
region. Telling of Paris' position on the distribution of rebuilding responsibilities in the rebuilding phase is the statement issued in the immediate aftermath of the intervention. President Sarkozy emphasised that 'the French army is not here to ensure the stability of any government whatsoever, even if it is a friendly government. Ivoirians must be the ones to choose' lvii. It is often argued that the French policy of African reflects an attempt to consolidate political and economic power of France in the continent ${ }^{\text {lviii }}$ and in such context, the above declaration represents nothing more than lip service to Ivorian sovereignty. Yet, what makes the statement interesting from the vantage point of norms is that the French government deemed necessary to refer to domestic ownership and responsibility of the rebuilding process. As long line of research on ideas and norms in world politics has shown, the ways in which states justify particularly courses of action are indicative of the normative environment within which policy-makers

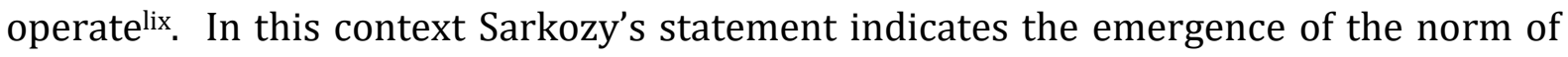
national responsibility/ownership of the rebuilding process, as argued earlier. The notion of domestic rebuilding responsibilities has not only informed France's engagement in the country, but also that of the UN. As the UNSMIL in Libya, the UN Operation in Côte d'Ivoire (UNOCI) has emphasised national ownership of and responsibility over the rebuilding process ${ }^{\mathrm{lx}}$. Even immediate post-intervention tasks, such as organising elections, traditionally the bread and butter of the UN peacebuilding missions have been transferred to domestic actors ${ }^{\mathrm{lxi}}$. 
The Ivorian rebuilding process since the 2011 intervention has largely focused on stimulating economic growth and reconstructing the physical infrastructure and significant progress has been achieved in this regard. Despite successes in the economic sphere, peace in Cŏte d'Ivoire remains of negative kind. As in Libya, the postintervention phase has been characterised by what is often referred to as victor's justice ${ }^{\text {lxii. }}$ The judicial system is highly politicised and lacks independence; prosecutions following the electoral violence that led to the protection intervention have targeted Outtara's rival Laurent Gbagbo and his supporters, while atrocities committed by the forces loyal to Outtara have so far remained uninvestigated. Although international human rights organisations have raised concerns over the lack of impartial transitional justice, international pressure on Outtara in this regard has been modest lxiii.

Competition over land ownership has been one of the key drivers of inter-communal conflict in the country and as such, key to addressing the root causes of conflict. In line with the ethos of domestic rebuilding responsibilities, the UNOCI has left resolving land disputes to domestic authorities ${ }^{\text {lxiv. }}$ Yet, as Mitchell ${ }^{\mathrm{xv}}$ points out, four years into the rebuilding process this fundamental source of conflict has been neglected by the Outtara government. Land distribution has, in fact, become an important source of power and influence in Ivorian politics; government officials are allegedly involved in illicit distribution of land ${ }^{\text {lxvi. }}$. Coupled with unresolved political questions, nationalism, expressed in the notion of Ivoirité, foregrounding a distinction between 'real' Ivoirians and non-native groups, has been used by political elites to fuel inter-communal conflict which has undermined the process of reconciliation. As the UNOCI is winding down its presence, the direction of political development after the 2011 intervention has been towards the pre-intervention status quo rather than building resilient and capable statelxvii.

In both cases post-intervention rebuilding responsibilities are understood as distinctly domestic obligations, even if the extent of international engagement is different. It would be simplistic to attribute the difficulties faced by Libyans and Ivoirians in the wake of the respective protection interventions to this factor alone. In both cases lack of agreement on political issues, such as constitutional arrangements or land ownership, have been major sources of conflict. It is clear that resolving such issues in a legitimate 
manner requires domestic ownership of the process. However, the cases highlight the problems that transferring the responsibility of post-intervention rebuilding to the domestic sphere with limited international engagement has resulted in. As noted earlier, Pillar II commitments in the aftermath of protection interventions have been largely been represented in terms of conflict prevention. Preventative measures consist of building a strong and stable institutions of state; representative governmental institutions, independent judiciary and security forces, inter alia. Although in the long run such statebuilding measures may be conducive to peace and stability, in the shortrun the process of statebuilding often has the opposite effect. Statebuilding has historically been, and still is, a process that generates instability and at times, violence lxviii. This is so as the reconfiguration of power, central to the statebuilding process, creates winners, losers and contestation as elites jockey for power. This is nowhere more evident than in Libya where armed struggle for power in the post-R2P intervention power vacuum has prompted some to raise the prospect for further intervention. In Côte d'Ivoire, too, human rights monitors have documented violence against the former President's Laurent Gbagbo's supporters. In the short-run then Pillar II activities may in fact generate greater need for Pillar III action instead of making it less likely. The emphasis on the responsibilities of domestic agents who may not have the capacity to halt violence or who may themselves be the sources of instability sits rather uneasily with the strategy of creating resilient and capable states through statebuilding.

A related point is that while the move away from externally-driven rebuilding processes is clearly a welcome development, the discourse on domestic obligations in the context of R2P serves to legitimize weak international commitment to follow through protection interventions where the immediate interests of the intervening states are not at stake. Rather than tying states into a responsibility to rebuild, the notion of domestic rebuilding obligations and the consequent Pillar II commitment by other states to assist in such process has in effect allowed states to retain more flexibility in their decisions to contribute to rebuilding operations. This stands in contrast to accounts that see the responsibility to rebuild as a rhetorical device to legitimize coercive liberal interventionism ${ }^{\text {xix }}$. In Libya more extensive international engagement has coincided with the wider concerns about the Islamic State and the gains it has made in Libya, 
whereas in Côte d'Ivoire France's commitment to the rebuilding process is seen to stem from its attempts to consolidate influence in Africa lxx. Although there is much to be said for the benefits of grounding the longer-term rebuilding and peacebuilding on domestic ownership, the cases raise the urgent question of whether these processes can be initiated without stronger commitment on the rebuilding phase by international actors.

\section{Conclusion}

This paper was motivated by the question of what happened to the idea of responsibility to rebuild which has largely disappeared out of policy and academic debates. It has been shown that what began as a set of clearly defined international obligations in the wake of protection interventions, has transformed into much broader and opaque Pillar II commitments to assist states following protection interventions. Both the UN Secretary General's reports on concerning Pillar II and the actual rebuilding strategies of donor governments and international statebuilding agencies on the ground reflect the shift away from international rebuilding responsibilities to distinctly domestic obligations. This conceptual recalibration has occurred because of the association the responsibility to rebuild with its more contested counterpart, the responsibility to react. At the same time, changes in the wider ideational environment within which rebuilding operations function rendered the notion of international rebuilding responsibilities short-lived. The experience of Libya and Côte d'Ivoire attest to the tension underpinning the simultaneous trend towards domestic responsibilities and the focus of R2P on prevention. Prevention, sought to achieve through the process of statebuilding, tends to generate instability. The capacity, and in certain cases the will, of domestic actors to effectively address this is often limited. This raises the question of what the aims of protection interventions are; bringing an end to violence or generating more positive forms of peace? The cases suggest that whereas much of the controversy on R2P has so far related to the implementation of the Pillar III, weak commitment to rebuilding may represent equal, if not, greater obstacle to the realisation of R2P. 


\section{The author wishes to thank the anonymous reviewers and Ramesh Thakur for their comments on the article.}

\footnotetext{
i For instance, Thomas G Weiss. RtoP alive and well after Libya. Ethics \& International Affairs, 25 no. 03 (2011): .287-292, Catherine Powell Libya: A Multilateral Constitutional Moment?. American Journal of International Law, 106 no. 2 (2012), 298-316,

ii Alex J Bellamy Libya and the Responsibility to protect: the Exception and the Norm. Ethics \& International Affairs, 25 no. 03 (2011), 263-269

iii Simon Chesterman "Leading from Behind": The Responsibility to Protect, the Obama Doctrine, and Humanitarian Intervention after Libya. Ethics \& International Affairs, 25 no.03 (2011), 279-285.

iv International Commission on Intervention and State Sovereignty The Responsibility to Protect (Ottawa, International Development Research Centre, 2001)

v Alex Bellamy 'Conflict Prevention and the Responsibility to Protect' Global Governance 14 no 2 (2008):135-156

vi Bellamy, 'Conflict Prevention and the Responsibility to Protect'

viiBrian Orend Jus post bellum. Journal of Social Philosophy, 31 no. 1 (2000), 117-137, Jean Bethke Elshtain The Ethics of Fleeing What America Still Owes Iraq. World Affairs, 170 no. 4 (2008), 91-98, Gary J Bass Jus post bellum. Philosophy \& public affairs, 32 no. 4 (2004), 384-412.

viii E.g. Elshtain The Ethics of Fleeing What America Still Owes Iraq

ix James Pattison 'Jus Post Bellum and the Responsibility to Rebuild' British Journal of Political Science, first review article, (2013), 1-27.

× Paul Robinson 'Is There an Obligation to Rebuild' in Alice MacLachlan and Allen Speight (eds.) Justice, Responsibility and Reconciliation in the Wake of Conflict ( Springer, Dordrecht, 2013), p.106

xi Albrecht Schnabel ' the Responsibility to Rebuild' in W Andy Knight and Fraser Egerton (eds) Routledge Handbook on the Responsibility to Protect. (Routledge, Abingdon, 2012)

xii Michael Newman Revisiting the 'responsibility to protect'. The Political Quarterly, 80 no. 1, (2009), 93

xiii Ibid, 93-94

xiv International Commission on Intervention and State Sovereignty, 'the Responsibility to Protect, 29

${ }^{x v}$ Kofi Annan, 'In Larger Freedom: towards Development, Security and Human Rights for All' A/59/2005.

xvi Andrew J Williams 'Reconstruction before the Marshall Plan' Review of International Studies 31 no. 3 (2005), 541

xvii Andrew J Williams 'Reconstruction before the Marshall Plan', 541

xviii Williams, 'Reconstruction before the Marshall Plan, 546

xix An Agenda for Peace, A/47/277-S/24111, 17 June 1992, paragraph 21

xx Francis Fukuyama (ed.) Nation-Building: Beyond Afghanistan and Iraq'(Baltimore, The Johns Hopkins University Press, 2006), 4

xxi Meera Sabaratnam 'the Liberal Peace? An Intellectual History of Conflict Management, 1990-2010' in

Susanna Campbell et al (eds.) A Liberal Peace? (London, Zed Books, 2011

xxii Schnabel, 'the Responsibility to Rebuild' also makes this point (p.53)

xxiii International Commission on Intervention and State Sovereignty 'the Responsibility to Protect' , 42

xxiv Ibid, 40,41

xxv A More Secure World: Our Shared Responsibility. High Level Panel on Threats, Challenges and Change

(New York: UN, 2004), paragraphs 201 - 203

xxvi International Coalition for the Responsibility to Protect, State-by-State Positions on the Responsibility to Protect. Available at: www.responsibilitytoprotect.org/files/Chart_R2P_11 August.pdf . Last accessed 29 March 2015.

xxvii Statement by Ambassador Munir Akram, Permanent Representative of Pakistan to the UN in the Open Debate of the Security Council on Protection of Civilians in Armed Conflict, New York, 9 December 2005. Available at: http://www.pakun.org/statements/Security_Council/2005/12092005-01.php. Last accessed 3 April 2015
} 
xxviii Non-Aligned Movement Statement on Responsibility to Protect, New York, April 2005. Available at: http://www.iilj.org/courses/documents/DevelopingCountryStatementsonR2P.pdf. Last accessed on 3 March 2015.

xxix International Coalition for the Responsibility to Protect, State-by-State Positions on the Responsibility to Protect

xxx Expressed, for instance, in the statements by the US government in the Security Council Open Debate on the Protection of Civilians in Armed Conflict in 28 June 2006 and 4 December 2006. Excerpts available through http://www.responsibilitytoprotect.org/index.php/component/content/article/35-r2pcstopics/2378-security-council-open-debates-on-the-protection-of-civilians. Last accessed 4 April 2015.

xxxi 'Implementing the Responsibility to Protect' A/63/677 12 January (2009), paragraphs 30 and 33

xxxii Ibid, paragraph. 37

xxxiii Ibid, paragraph 47

xxxiv ' Responsibility to Protect: Timely and Decisive Response’ A/66/874 25 July (2012), paragraph 15

xxxv 'Fulfilling Our Collective Responsibility: International Assistance and the Responsibility to Protect'

A/68/947 11 July (2014)

xxxvi For instance, Steven Bernstein Ideas, Social Structure and the Compromise of Liberal

Environmentalism European Journal of International Relations 6 no. 4 (2000); 464-512

xxxvii Bernstein 'Ideas, Social Structure and the Compromise of Liberal Environmentalism', 483

xxxviii Ann Florini The Evolution of International Norms International Studies Quarterly 40 no.3 (1996);

363-389

xxxix Edward Luck 'from Promise to Practice: Implementing the Responsibility to Protect' in Jared Genser et al (eds.) The Responsibility to Protect: the Promise of Stopping Mass Atrocities in Our Time (New York, Oxford University Press, 2012)

xl Luck 'from Promise to Practice, 95

xii David Hannay New World Disorder (London, I.B Tauris, 2008), 252

xlii OECD, 'the Paris Declaration on Aid Effectiveness and the Accra Agenda for Action' (2005), available at: http://www.oecd.org/dac/effectiveness/34428351.pdf. Last accessed 1 March 2015

xliii Rob Jenkins The UN Peace-building Commission and the Dissemination of International Norms. Crisis States Research Centre, 2008, 9.

xliv Ibid, 16 - 18

xlv International Dialogue on Peacebuilding and Statebuilding, 'a New Deal on Engagement with Fragile States'. Available at: http://www.pbsbdialogue.org//documentupload/49151944.pdf, last accessed 2 February 2015

xlvi Council of Europe ' Opinion on the Constitutional Situation in Bosnia and Herzegovina and the Powers of the High Representative Adopted by the Venice Commission at its $62^{\text {nd }}$ Plenary Session. Available at: http://www.venice.coe.int/webforms/documents/CDL-AD\%282005\%29004-e.aspx. Last accessed 3 March 2015

xlvii Ethan Chorin 'NATO's Libya Intervention and the Continued Case for a Responsibility to Rebuild'. Boston University International Law Journal 31 no 365 (2013), 377: Jason Pack and Barak Barfi In War's Wake: The Struggle for Post-Qadhafi Libya. Washington Institute for Near East Policy, 2012, 19.

xlviiiInternational Crisis Group 'Trial by Error: Justice in Post-Qadhafi Libya' Middle East/North Africa Report $N^{\circ} 140,17$ Apr 2013

xlix Jason Pack, Karim Mezran and Mohamed Eljarh Libya's Faustian Bargains: Breaking the Appeasement Cycle. Atlantic Council, Rafik Hariri Center for the Middle East, 2014, 44.

'Colum Lynch ' Libyan Opposition Leaders Rule Out Major Role for Foreign Peacekeepers; UN Shifts Planning' Washington Post 29 August 2011. Available at

http://www.washingtonpost.com/blogs/checkpoint-washington/post/libyan-opposition-rules-outmajor-role-for-peacekeepers/2011/08/29/gIQAdwmynJ_blog.html. Last accessed 2 December 2014. li UN Security Council Resolutions S/RES/2009 (16 September 2011) and S/RES/2040 (12 March 2012)

lii Paris Communiqué paragraph 5

liii Ian Martin 'United Nations post-conflict deployment in Libya'. 2011 Available at: http://www.innercitypress.com/martin1unlibya1icp.pdf. Last accessed 1 August 2014.

liv Ibid, paragraph 8. NATO's policy has, however, been rather different. . From the outset the NATO's strategy has been premised on the policy of 'no boots on the ground' with little appetite for peacekeeping force.

Iv Nicholas Cook 'Côte d'Ivoire post-Gbabgo: Crisis Recovery' Congressional Research Service, April 20,

2011,10 


\footnotetext{
Ivi Bruno Charbonneau ' the Imperial Legacy of International Peacebuilding: the Case of Francophone Africa' Review of International Studies 40 no 3 (2014), 607-630

lvii Cited in Charbonneau ' the Imperial Legacy of International Peacebuilding: the Case of Francophone Africa', 621

lviii Ibid. Also Luis Simon 'the Spider in Europe's Web? French Grand Strategy from Iraq to Libya' Geopolitics 18 no 2, 403-434

lix For example, Martha Finnemore 'Constructing Norms of Humanitarian Intervention' in Peter Katzenstein (ed.) The Culture of National Security: Norms and Identity in World Politics (New York, Columbia University Press, 1996), pp. 153-185.

Ix UN Security Council Resolution S/RES/2162 (25 June 2014)

Ixi UN Security Council Resolutions S/RES/2000 (27 July 2011) and 2162 ( 25 June 2014)

lxii Maja Bovcon 'the Progress in Establishing the Rule of Law in Côte d'Ivoire under Outtara's Presidency'

Canadian Journal of African Studies 48 no 2 (2014), 185-202

Ixiii Bovcon, 'the Progress in Establishing the Rule of Law in Côte d'Ivoire under Outtara's Presidency', 193,198

lxiv Matthew I Mitchell 'Land Tenure Reform and Politics in Post-Conflict Côte d'Ivoire' Canadian Journal of African Studies, 48 no 2 (2014), 213

lxv Ibid

Ixvi International Crisis Group ' Côte d'Ivoire’s Great West: Key to Reconciliation' Report No.212, January 2014, p.7

lxvii International Crisis Group 'Côte d'Ivoire: Defusing Tensions' Report No.193, November 2012, p.17

lxviii This point is cogently illustrated in Marta Iniguez de Heredia 'Escaping Statebuilding: Resistance and Civil Society in the Democratic Republic of Congo' Journal of Intervention and Statebuilding 6 no 1 (2012), 75-89

Ixix Robinson 'Is There an Obligation to Rebuild'

${ }^{1 \times x}$ Charbonneau ' the Imperial Legacy of International Peacebuilding: the Case of Francophone Africa'
} 